\title{
ANALYSIS OF FACTORS CAUSING TRAFFIC ACCIDENTS ON SULTAN AGUNG STREET, BEKASI
}

\author{
Andri Irfan, RIFAI \\ Faculty of Engineering \\ Mercu Buana University, Indonesia \\ andrirfan@yahoo.com \\ Eka Satria, AULIA \\ Faculty of Engineering \\ Mercu Buana University, Indonesia \\ ekasatria96@gmail.com
}

\begin{abstract}
Sultan Agung Street is the main road in Bekasi City which has a length of $5.5 \mathrm{~km}$. On the Sultan Agung Street, there are many settlements and public facilities. However, this condition was not matched by adequate road infrastructure and public transportation facilities and infrastructure. This causes an increase in the volume of traffic and potential for accidents on Sultan Agung street. The purpose of this study was to determine the dominant causal factors of accidents and to determine efforts to prevent accidents on Jalan Raya Sultan Agung with the Upper Control Limit (BKA) and Upper Control Limit (UCL) methods. Based on the analysis of Sultan Agung Bekasi Street included in the category of accident-prone roads because there are two road segments having AEK values exceeding the BKA and UCL values. The coordinate point of the location with the highest $A E K$ value is the third segment with an $A E K$ value of 195 where the BKA value is 122,894 and the UCL value is 119,333 . The most common type of accident is a Front-Rear hit by $37.5 \%$ of the total number of accidents. Time of accidents most often occurs at night with a percentage of $56 \%$ of the number of accidents.
\end{abstract}

Keywords: Roads; Traffic Accidents; Accident Equivalent Number

\section{INTRODUCTION}

West Java Province is one of the provinces with the largest population in Indonesia with a population of 49.02 million people. The three cities / cities that have the most population are Bogor with a population of 5.8 million, Bandung with a population of 3.7 million, and Bekasi with a population of 3.7 million. Sultan Agung Street is one of the main roads in Bekasi City. Sultan Agung Street has a length of $5.5 \mathrm{~km}$ which connects Bekasi Raya Street with Jend. Sudirman Bekasi Street. On the side of Sultan Agung Street, there are many settlements, education centers, commercial areas, hospitals, markets and Bekasi City Parks. This affects the level of traffic density on Sultan Agung Street. However, this condition is not balanced with adequate road infrastructure and public transportation. Seen from the many local roads leading directly to the arterial road which resulted in many points of conflict between road users. Of course this has caused an increase in traffic volume on Sultan Agung Street and also increased the potential for accidents.

\section{LITERATURE REVIEW}

Roads and Traffic Accidents

Road is a land transportation infrastructure that covers all parts of the road, including complementary buildings and equipment intended for traffic, which are on the surface of the land, above the surface of the land, below the surface of the land and or water, and above the water level, except railroad, road lorries and cable roads [19]. 
VOLUME 18 | NUMBER 02 | JANUARY 2019

https://ejournal.worldconference.id/index.php/neutron E-ISSN: 2685-3272 I P-ISSN 1412-0860

According to [12], the division of authority of roads is divided into several sections namely:

1. National Road, is the road that connects provinces (between provinces) in an area under the authority of the State in this case the Ministry of Public Works where if in the area held by a Specific Non Vertical Team (SNVT)

2. Provincial Road, the road that connects between cities / cities in a province

3. City Roads, public roads on the secondary road network in the city.

4. Regency Road, the road that connects between villages / villages

5. Village roads, primary environmental roads and primary local roads that do not include City roads and are public roads that connect the area and / or between settlements within the village.

A traffic accident is an unexpected and unintentional road event involving a vehicle with or without other road users resulting in human casualties and / or property loss. Traffic accidents can be caused by negligence of road users, vehicle mismanagement, and road and / or environmental roadworthiness. Traffic accidents are classified into three, namely minor traffic accidents, moderate traffic accidents, and heavy traffic accidents. Minor traffic accidents are accidents that result in damage to vehicles and / or goods. A moderate traffic accident is an accident that causes minor injuries and damage to vehicles and / or goods. Heavy traffic accidents are accidents that result in death or serious injury [18].

\section{Accident Characteristics}

\section{Accidents Based on Accident Victims}

Based on [20], the classification of victims of traffic accidents is as follows:

1. Death victim, is a victim who is confirmed to have died as a result of a traffic accident within a maximum period of 30 (thirty) days after the accident.

2. Victims of serious injuries, are victims who have sustained permanent disability or must be treated for more than 30 (thirty) days since the accident occurred.

3. Victims of minor injuries, are victims who do not need help or treatment in hospital or treated for no more than 30 days.

\section{Accident Based on Collision Type}

Traffic accidents are divided into several types based on collisions that occur namely:

1. Front-front collision, is a type of collision between two speeding vehicles where the two fronts of the vehicle collide with each other.

2. Front-rear collision, is a type of collision between two or more vehicles that go in the same direction where one front of the vehicle crashes into the back of the other vehicle.

3. Side collision - side, is a type of collision between two speeding vehicles where the side of one vehicle crashes into the side of the other vehicle.

4. Front-side collision, is a type of collision between two vehicles where the front of the vehicle crashes into the side of another vehicle. This type of collision is common at intersections or parking lots.

5. Rolled over (Rollover), is a type of collision where the vehicle experiences a roll or overturn. The cause of overturning is usually due to vehicle instability when it is at high speed corners or sharp turns.

\section{Accidents Based on the Time of the Accident}

According to the guidelines of Pd T-09-2004-B regarding Handling of Traffic Accident Prone Locations, the time of the accident occurrence can be viewed from the lighting conditions at the crime scene or the hour of the accident.

1. In terms of lighting conditions, the time of occurrence is divided into:
a. Dark night / no lighting,
b. The night there is lighting,
c. Good afternoon, 
d. Dark afternoon (rain, fog, smoke)

e. Dawn or dusk.

2. Reviewed from the hour of the incident refers to the time period contained in the accident data form.

\section{Accident Prone Location Identification}

There are methods that can be used to identify accident prone locations, namely the Accident Equivalent Number (AEK) method. According to Pd T-09-2004-B guidelines regarding Handling of Traffic Accident Prone Locations, AEK is a number used for weighting accident classes, this number is based on the value of accidents with damage or material loss.

To weight the level of accidents that occur on the road, it is done by utilizing a comparison of the monetary value of the cost of the accident, with a comparison:

M: B: R: K = M / K: B / K: R / K: 1 (2.1)

with:

$M=$ died

$B=$ Severe injuries

$\mathrm{R}=$ minor injuries

$\mathrm{K}=$ Accident with material / material loss

By utilizing the comparison of the monetary value of accident costs, the equivalent number of accidents with the weighting system can be used, which refers to accident costs:

Table 1 Standard Weighting Value Table

\begin{tabular}{|c|c|}
\hline Fatality rate & Weight \\
\hline died $(\mathrm{M})$ & 12 \\
\hline Severe injuries (B) & 3 \\
\hline minor injuries (R) & 3 \\
\hline Accident with material / material loss (K) & 1 \\
\hline
\end{tabular}

Source: Department of Settlement and Regional Infrastructure (Pd-T-09-2004-B)

Accident Equivalence Rate (AEK) is calculated by summing each victim's fatality rate multiplied by the weight according to the severity. The AEK formula is as follows:

$$
A E K=12 M+3 B+3 R+1 K
$$

The determination of accident-prone locations is based on the number of each kilometer of the road that has an AEK weight value exceeding a certain limit. This boundary value is calculated using the Upper Control Limit (BKA) or Upper Control Limit (UCL) method.

The Upper Control Limit (BKA) value is determined using the following formula:

$$
B K A=C+3 \sqrt{ } C
$$

With:

$C=$ Average accident equivalent number (AEK).

Determination of accident-prone locations using quality control statistics as a UCL (Upper Control Limit) control chart

$$
U C L=\lambda+\Psi \times \sqrt{ }((\lambda / m+0.829 / m+(1 / 2 \times m)))
$$

With:

UCL $=$ Upper limit control line

$\lambda=$ Average accident rate in exposure accident units

$\Psi=$ Probability Factor $(\Psi=2.576)$

$\mathrm{M}=$ Unit of exposure, $\mathrm{km}$ 
Road segments with accident rates or AEK that are above the BKA or UCL lines are defined as accident-prone locations.

\section{RESEARCH METHODOLOGY}

Research Location and Time

Research Analysis was conducted on Sultan Agung Street, Bekasi. The time of writing this research was carried out in September 2018 - January 2019 using data on traffic accidents in 2015 - 2018.

\subsection{Methods of Analyzing Accident Management Efforts}

The purpose of this analysis is to provide an effort to handle accidents at the accident location on Sultan Agung Street based on the accident situation at that location. This analysis can be done after seeing the types of accidents that are considered dominant at accident-prone locations. After obtaining the dominant type of accident at the accident site, a survey of the road conditions and / or completeness of the road safety facilities at the accident-prone location to obtain appropriate handling recommendations.

\section{RESULTS AND DISCUSSION}

Data Analysis

Secondary Data Analysis

Tabel 2 Recapitulation of Sultan Agung Street Accident Data

\begin{tabular}{|c|c|c|c|c|}
\hline \multirow{2}{*}{ Description } & \multicolumn{4}{|c|}{ Years } \\
\cline { 2 - 5 } & 2015 & 2016 & 2017 & 2018 \\
\hline Number of accident occurrences & & & & \\
\hline Number of accidents without injury & 2 & 0 & 1 & 1 \\
\hline Number of Accidents causing injuries & 17 & 15 & 5 & 18 \\
\hline The number of accidents causes death & 1 & 7 & 5 & 8 \\
\hline Total & $\mathbf{2 0}$ & $\mathbf{2 2}$ & $\mathbf{1 1}$ & $\mathbf{2 7}$ \\
\hline Number of Victims & & & & \\
\hline Number of Victims of Minor Injuries & 16 & 18 & 4 & 32 \\
\hline Number of victims of serious injuries & 8 & 1 & 2 & 2 \\
\hline Number of Death Victims & 1 & 7 & 5 & 9 \\
\hline Total & $\mathbf{2 5}$ & $\mathbf{2 6}$ & $\mathbf{1 1}$ & $\mathbf{4 3}$ \\
\hline Number of Vehicles Involved & & & & \\
\hline A single accident & 14 & 18 & 7 & 19 \\
\hline Accident Involves Two Vehicles & 5 & 4 & 4 & 8 \\
\hline Accident Involves Three Vehicles & 1 & 0 & 0 & 0 \\
\hline Total & $\mathbf{2 0}$ & $\mathbf{2 2}$ & $\mathbf{1 1}$ & $\mathbf{2 7}$ \\
\hline Number of Factors Causing Accidents & & & & \\
\hline Driver Factor & 16 & 18 & 10 & 23 \\
\hline Vehicle Factor & 2 & 3 & 1 & 4 \\
\hline Road and Environmental Factors & 2 & 1 & 0 & 0 \\
\hline Total & $\mathbf{2 0}$ & $\mathbf{2 2}$ & $\mathbf{1 1}$ & $\mathbf{2 7}$ \\
\hline Accident time & & & & \\
\hline
\end{tabular}


VOLUME 18 | NUMBER 02 | JANUARY 2019

https://ejournal.worldconference.id/index.php/neutron E-ISSN: 2685-3272 I P-ISSN 1412-0860

\begin{tabular}{|c|c|c|c|c|}
\hline \multirow{2}{*}{ Description } & \multicolumn{4}{|c|}{ Years } \\
\cline { 2 - 5 } & 2015 & 2016 & 2017 & 2018 \\
\hline Daytime & 12 & 7 & 5 & 11 \\
\hline Evening & 8 & 15 & 6 & 16 \\
\hline Total & $\mathbf{2 0}$ & $\mathbf{2 2}$ & $\mathbf{1 1}$ & $\mathbf{2 7}$ \\
\hline
\end{tabular}

Source: Bekasi City Polrest

\section{Primary Data Analysis}

Primary data were obtained from the results of a field survey on the Sultan Agung Street section using a checklist form and comparing the actual conditions in the field with minimum road service standards regarding the substance of safety at accident prone locations.

Based on the survey results of road conditions, traffic sign, and road infrastructure, there are several factors that cause traffic accidents on Sultan Agung Street, rhat is:

1. Sultan Agung Bekasi Street is a provincial road that connects Bekasi City and East Jakarta City where the level of mobilization on Sultan Agung Street is quite crowded, especially during rush hour. The majority of people who work in East Jakarta and North Jakarta areas pass through Sultan Agung Street for driving access. However, due to the high volume of vehicles on Sultan Agung Street, the condition of road facilities and infrastructure is still inadequate.

2. The large number of factory areas, education centers, hospitals, shops, and other public facilities along Sultan Agung street causes many pedestrians to walk along the road or cross. However, in Figure 4.3, there is still a lack of placement of zebra crossing or faded from zebra crossing and road markings causing less visible to riders. Plus there are also several road points that are not affected by street lighting due to obstruction of street lights by trees.

\section{Analysis of Accident Prone Areas}

The analysis of accident-prone areas in this study uses the Accident Equivalent Number (AEK) method. This method is used to determine accident-prone areas by ranking AEK values with the Upper Control Limit (BKA) and Upper Control Limit (UCL) values based on the number and fatality rate of accident victims that occur on Sultan Agung street.

Accident Equivalence Rate (AEK) is calculated by summing each victim's fatality rate multiplied by the weight according to the severity.

AEK formula:

$$
A E K=12 M D+3 L B+3 L R+1 K
$$

The AEK calculation reviewed is on Sultan Agung street which is divided into 6 segments with the length per segment being a maximum of $1 \mathrm{~km}$.

BKA calculations can be calculated using the average value of AEK on the reviewed road section.

BKA formula

$$
\mathrm{BKA}=\mathrm{C}+3 \sqrt{ } \mathrm{C}
$$

Where the value of $C$ is the average accident equivalent number (AEK).

$U C L$ calculations can be calculated using the average value of AEK on the road section being reviewed.

UCL formula

$$
\mathrm{UCL}=\lambda+\Psi \times \sqrt{\left(\frac{\lambda}{m}+\frac{0,829}{m}+\left(\frac{1}{2} x m\right)\right)}
$$




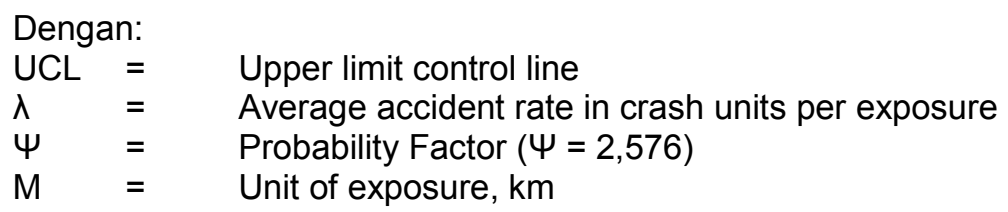

The results of the calculation of the identification of accident-prone locations by the AEK method can be seen in Table 4.2.

Tabel 3 Calculation of Identification of Accident Prone Locations

\begin{tabular}{|c|c|c|c|c|c|c|c|}
\hline \multirow{2}{*}{$\begin{array}{c}\text { Lenght } \\
(\mathrm{km})\end{array}$} & \multicolumn{3}{|c|}{ AEK } & \multicolumn{4}{c|}{ Nilai } \\
\cline { 2 - 6 } & $12 \mathrm{MD}$ & $3 \mathrm{LB}$ & $3 \mathrm{LR}$ & $1 \mathrm{~K}$ & AEK & BKA & UCL \\
\hline 1 & 60 & 21 & 54 & 23 & 158 & & 116.8 \\
\hline 1 & 48 & 3 & 51 & 10 & 112 & & 113.3 \\
\hline 1 & 108 & 18 & 48 & 21 & 195 & \multirow{3}{*}{123} & 119.3 \\
\hline 1 & 24 & 0 & 21 & 9 & 54 & & 107.6 \\
\hline 1 & 0 & 3 & 27 & 6 & 36 & & 105.5 \\
\hline 0.5 & 0 & 0 & 6 & 2 & 8 & & 104.1 \\
\hline \multicolumn{7}{|c|}{ Source: Calculation Results }
\end{tabular}

Analysis of the Data Analysis Approach

Factors Causing Accidents

Table 4. Percentage of Factors that Cause Sultan Agung Street Accidents

\begin{tabular}{|c|c|c|c|}
\hline \multicolumn{4}{|c|}{ DRIVING FACTOR } \\
\hline Numb. & Factors Causing Laka & Amount & Percentage \\
\hline 1 & Less skilled & 3 & $3.75 \%$ \\
\hline 2 & Tired & 12 & $15.00 \%$ \\
\hline 3 & Careless & 18 & $22.50 \%$ \\
\hline 4 & Drunk & 0 & $0.00 \%$ \\
\hline 5 & Undisciplined & 34 & $42.50 \%$ \\
\hline 6 & Visibility is lacking & 0 & $0.00 \%$ \\
\hline & Sub-Total & 67 & $83.75 \%$ \\
\hline \multicolumn{4}{|c|}{ VEHICLE FACTORS } \\
\hline No. & Factors Causing Laka & Amount & Percentage \\
\hline 1 & Technical conditions are not feasible & 8 & $10.00 \%$ \\
\hline 2 & $\begin{array}{l}\text { Use not in accordance with the } \\
\text { provisions (Overload) }\end{array}$ & 2 & $2.50 \%$ \\
\hline 3 & $\begin{array}{c}\text { Vehicle lighting is not in accordance } \\
\text { with the provisions }\end{array}$ & 0 & $0.00 \%$ \\
\hline & Sub-Total & 10 & $12.50 \%$ \\
\hline \multicolumn{4}{|c|}{ ROAD / ENVIRONMENTAL FACTORS } \\
\hline Numb. & Factors Causing Laka & Amount & Percentage \\
\hline 1 & Weather & 0 & $0.00 \%$ \\
\hline
\end{tabular}


VOLUME 18 | NUMBER 02 $\mid$ JANUARY 2019

https://ejournal.worldconference.id/index.php/neutron E-ISSN: 2685-3272 I P-ISSN 1412-0860

\begin{tabular}{|c|c|c|c|}
2 & $\begin{array}{c}\text { Road facilities are not in accordance } \\
\text { with the provisions }\end{array}$ & 2 & $2.50 \%$ \\
\hline 3 & Road Geometric & 1 & $1.25 \%$ \\
\hline 4 & Traffic flow & 0 & $0.00 \%$ \\
\hline \multicolumn{2}{|c|}{ Sub-Total } & 3 & $3.75 \%$ \\
\hline Total Accident & $\mathbf{8 0}$ & $\mathbf{1 0 0 . 0 0 \%}$ \\
\hline
\end{tabular}
source: calculation results

Figure. 5 Circle Diagram of Factors Causing Accidents

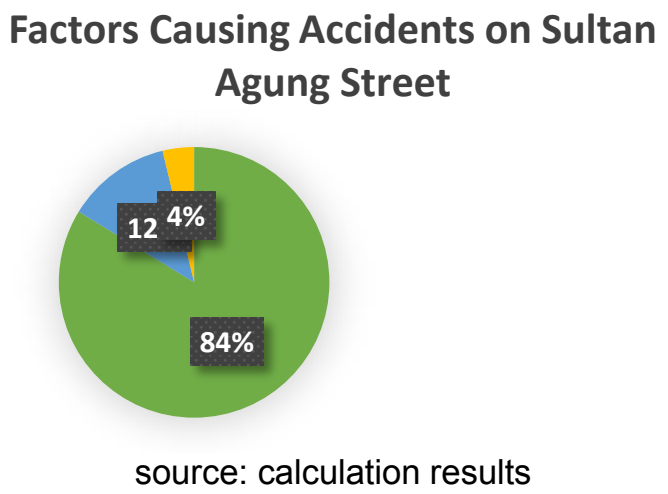

Accident Type

Fig. 1 Accident Type Circle Diagram on Sultan Agung

Type of Accident on Sultan Agung Street

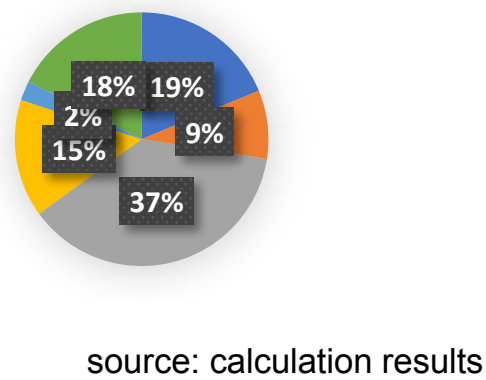

Accident Time

Fig 2 Accident Time Circle Diagram on Sultan Agung Street

Time of Accident on Sultan Agung Street

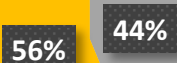

source: calculation results 


\section{CONCLUSION}

1. Based on the results of the analysis of accident-prone locations in Sultan Agung Bekasi Street in 2015 - 2018 using the Accident Equivalent Number (AEK), Upper Control Limit (BKA), and Upper Limit Control (UCL) methods, it was concluded that Sultan Agung Bekasi street is included in the category of vulnerable roads traffic accidents, because there are two road segments that have AEK values exceeding or greater than the value of the BKA and UCL. The coordinate point of the location with the highest AEK value is the third segment at the coordinate point $3(L=-6.219320 ; B=106.973793$ to $L=-6.231014 ; B=106.987367)$ from the front of Ananda Hospital - Darulmuhsiniin Mosque with AEK value of 195 where the value of BKA is only 122,894 and UCL value is 119,333 . In this segment there have been 31 accidents with a total of 9 people killed, 6 people seriously injured, 29 people slightly (minor) injured, and 15,550,000 Rupiah in material losses. The most frequent types of accidents occurring on Sultan Agung Street in 2015-2018 are Front-Rear collision which is $37.5 \%$ of the total number of accidents while the most frequent time of accidents on Sultan Agung Street is at night with a percentage of $56 \%$ of accidents.

2. Factors causing traffic accidents on Sultan Agung Bekasi Street in 2015-2018 include:

a. The driver factor is the most dominant factor causing accidents with a percentage of $83.75 \%$ with the majority of drivers who do not order traffic.

b. Lack of facilities for pedestrians such as zebra crossing to cross the road, the colors of road markings and sidewalks have faded, the surface of the road there are many holes or puddles and patches of holes that arise, and there are some road points that are not exposed to lighting to be additional factors that can triggered an accident.

Suggestion

1. Counseling about the importance of safe driving or safety riding for the drivers and conducting special operations from the police in the field of traffic to deal with traffic problems or things that can trigger traffic accidents.

2. There are improvements on Sultan Agung Street including: Making zebra crossing for pedestrians, repainting road markings and sidewalks, repairing potholes, and adding supporting signs.

3. Additional analysis is needed to complete secondary data such as the number of vehicles involved, weather, gender and age of the victim. And other methods can also be used to determine accident-prone points on Sultan Agung street to get more accurate results.

\section{REFERENCES}

[1] Badan Pusat Statistik. (2017). Statistik Transportasi Darat. Jakarta: Badan Pusat Statistik Republik Indonesia.

[2] Clarke, D. D., Eard, P., Bartle, C., \& Truman, W. (2010). Accident Analysis and Prevention. Older Drivers' Road Traffic Crashes in the UK.

[3] Clarke, D. D., Eard, P., Bartle, C., \& Truman, W. (2010). Accident Analysis and Prevention. Killer crashes: Fatal road traffic accidents in the UK.

[4] Departemen Permukiman dan Prasarana Wilayah. (2004). Penanganan Lokasi Rawan Kecelakaan Lalu Lintas. Jakarta.

[5] Dhakal, K. P. (2018). Journal of Health Promotion. Road Traffic Accidents in Kathmandu Valley.

[6] K, R. E., \& Sharif, S. U. (2012). International Journal of Emerging Technology and Advanced Engineering. Prioritization of Accident Black Spots using GIS.

[7] Khisty, C. J., \& Lall, B. K. (2003). Transportation Engineering: An Introduction/Third Edition. Portland: Pearson Education, Inc. 


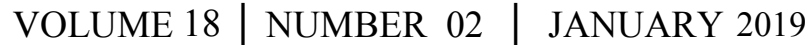

[8] Moafian, G., Aghabeigi, M. R., Heydari, S. T., Hoseinzadeh, A., Lankarani, K. B., \& Sarikhani, Y. (2013). Chinese Journal of Traumatology. An epidemiologic Survey of Road Traffic Accidents in Iran: Analysis of Driver-Related Factors.

[9] Moafian, G., Aghabeigi, M. R., Heydari, S. T., Hoseinzadeh, A., Lankarani, K. B., \& Sarikhani, Y. (2013). Chinese Journal of Traumatology. Educational Level and Age as Contributing Factors to Road Traffic Accidents.

[10] O'Flatherty, C. A., Nash, C. A., Bell, M. G., Bonsall, P. W., Leake, G. R., \& May, A. D. (1997). Transport Planning and Traffic Engineering. Amsterdam: Elsevier.

[11] Peraturan Menteri Perhubungan Republik Indonesia Nomor PM 34 Tahun 2014. (n.d.). Marka Jalan. Jakarta.

[12] Peraturan Pemerintah No.34 Tahun 2006. (n.d.). Jalan. Jakarta.

[13] Peraturan Pemerintah No.44 Tahun 1993. (n.d.). Lalu Lintas dan Angkutan Jalan. Jakarta.

[14] Rahmadi, S. (2011). Kecelakaan Lalu Lintas di Kecamatan Duren Sawit Jakarta Timur.

[15] Salim, P., \& Salim, Y. (2002). Kamus Bahasa Indonesia Kontemporer. Jakarta: Modern English Press.

[16] Sugiyanto, G. (2017). ARPN Journal of Engineering and Applied Sciences . The Cost of Traffic Accident and Equivalent Accident Number In Developing Countries (Case Study In Indonesia).

[17] Sugiyanto, G., Fadli, A., \& Santi, Y. (2017). ARPN Journal of Engineering and Applied Sciences. Identification of Black Spot and Equivalent Accident Number Using Upper Control Limit Method.

[18] Undang-Undang Republik Indonesia No.22 Tahun 2009. (n.d.). Lalu Lintas dan Angkutan Jalan. Jakarta.

[19] Undang-Undang Republik Indonesia No.38 Tahun 2004. (n.d.). Jalan. Jakarta.

[20] Undang-Undang Republik Indonesia Nomor 43 Tahun 1993. (n.d.). Prasarana dan Lalu Lintas Jalan. Jakarta.

[21] Valent, F., Schiava, F., Savonitto, C., Gallo, T., Brusaferro, S., \& Barbone, F. (2002). Accident Analysis and Prevention. Risk factors for fatal road traffic accidents in Udine, Italy. 